\title{
Therapeutic implications of copper deficiency in Menkes's steely-hair syndrome
}

\author{
J. A. WALKER-SMITH, B. TURNER, J. BLOMFIELD, and G. WISE \\ From the Department of Gastroenterology and Children's Medical Research Foundation, Royal Alexandra Hospital for \\ Children, Camperdown; and Prince of Wales Hospital, Randwick, N.S.W., Australia \\ Walker-Smith, J. A., Turner, B., Blomfield, J., and Wise, G. (1973). Archives \\ of Disease in Childhood, 48, 958 . Therapeutic implications of copper deficiency \\ in Menkes's steely-hair syndrome. The clinical features and state of copper \\ deficiency is reported in 3 children with Menkes's steely-hair syndrome. Therapy \\ with intramuscular copper EDTA in one child successfully raised plasma copper levels \\ but had no effect on the child's neurological status. Early diagnosis in the child at \\ risk before neurological damage has occurred, followed by parenteral therapy with \\ copper EDTA, offers the best management at present of this disease.
}

Copper deficiency in children with Menkes's kinky-hair syndrome was first reported in 1972 by Danks et al. (1972b). In 2 children studied, copper absorption appeared defective.

The purpose of this report is to describe briefly the clinical features of 3 children with this disorder, to report further observations of their state of copper deficiency, and to relate these observations to the management of this condition. In addition, details of parenteral treatment of copper deficiency in one child is presented. Some details of copper studies from these children from Sydney were briefly reported by Danks et al. (1972b).

Danks, Cartwright, and Stevens (1973) have recently suggested that the term 'kinky hair' is misleading and that the term 'steely hair' more accurately describes the appearance of the hair in this syndrome. We have adopted this name, therefore.

Received 26 June 1973.

\section{Clinical features (Table I)}

All 3 children were boys whose ages at the time of onset of initial symptoms ranged from 6 weeks to 6 months. In 2 vomiting was the symptom precipitating admission to hospital. All 3 had been regarded as normal infants initially, but their developmental progress had begun to slow shortly before the onset of more obvious symptoms. In 2 convulsions occurred shortly after admission to hospital. Gross abnormalities of the hair, namely loss of pigment and alteration in texture, had been noted by the parents shortly before the onset of other symptoms. At diagnosis all had pili torti.

Neurological development largely ceased from the time of diagnosis, and their final status was that of spastic quadraparesis.

In each of the 3 cases there was a family history of death in a male relative, which is in agreement with the sex-linked recessive inheritance characteristic of this condition.

\section{Pathology}

All 3 children died and necropsy studies showed the characteristic pathology of the condition (Table II).

TABLE I

Age of onset of symptoms

\begin{tabular}{|c|c|c|c|c|}
\hline Case no. * & $\begin{array}{l}\text { Age of onset of } \\
\text { symptoms }\end{array}$ & First symptoms & $\begin{array}{l}\text { Age of onset of } \\
\text { convulsions }\end{array}$ & Age at diagnosis \\
\hline $\begin{array}{l}3 \\
5 \\
4\end{array}$ & $\begin{array}{l}9 \mathrm{wk} \\
6 \mathrm{mth} \\
6 \mathrm{wk}\end{array}$ & $\begin{array}{l}\text { Vomiting } \\
\text { Vomiting and } \\
\text { diarrhoea } \\
\text { Floppiness, } \\
\text { feeding } \\
\text { difficulty }\end{array}$ & $\begin{array}{l}9 \mathrm{wk} \\
6 \mathrm{mth} \\
6 \mathrm{mth}\end{array}$ & $\begin{array}{r}3 \mathrm{mth} \\
18 \mathrm{mth} \\
8 \mathrm{mth}\end{array}$ \\
\hline
\end{tabular}

^Case numbers from Danks et al. (1972b). 
TABLE II

Pathological findings

\begin{tabular}{c|c|c|c|c|}
\hline Case no.* & Cerebrum & Cerebellum & Arteries \\
\hline 3 & $\begin{array}{c}\text { Patchy sclerosis } \\
\text { consistent with } \\
\text { vascular aetiology } \\
\text { Reduction in white } \\
\text { matter } \\
\text { Reduction in white } \\
\text { matter }\end{array}$ & $\begin{array}{c}\text { Diffuse atrophy and } \\
\text { gliosis } \\
\text { Diffuse atrophy }\end{array}$ & $\begin{array}{c}\text { Tortuous, patchy intimal } \\
\text { changes }\end{array}$ & Bronchopneumonia \\
Tiffuse atrophy & $\begin{array}{c}\text { Tortuous, patchy intimal } \\
\text { changes } \\
\text { Tortuous, patchy intimal } \\
\text { changes }\end{array}$ & $\begin{array}{c}\text { Meningitis, } \\
\text { bronchopneumonia }\end{array}$ \\
\hline
\end{tabular}

^Case numbers from Danks et al. (1972b).

The pathological features of Menkes's syndrome have recently been reviewed by Danks et al. (1972a). The present cases substantiate their findings regarding cerebral and arterial pathology. It is, however, more likely that defective cytochrome oxidase activity in the brain is responsible for much of the cerebral pathology, in particular the cerebellar lesion and the myelin pallor noted in all cases. This would be in accord with the findings of Gallagher and Reeve (1971) of deficient phospholipid synthesis in the brains of copper-deficient rats.

\section{Methods}

Copper studies. Plasma total and free copper were measured by the atomic absorption method of Blomfield and MacMahon (1969), and plasma copper oxidase by the method of Ravin (1961). Plasma copper oxidase was estimated for reasons of convenience rather than plasma caeruloplasmin. Biopsy liver copper was determined on dried biopsy samples by the carbon rod atomizer atomic absorption method of Stevens (1972). Necropsy liver and brain copper were assessed on samples which were dried to constant weight in vacuo over phosphorus pentoxide, ashed overnight at $450^{\circ} \mathrm{C}$ in platinum crucibles, dissolved in copper-free $4 \mathrm{~N}$ hydrochloric acid, and estimated by atomic absorption spectrophotometry.

\section{Results}

Clinical. A state of copper deficiency was shown in all 3 children, with low total plasma copper levels and low plasma caeruloplasmin levels (Table III).

TABLE III

Plasma copper and caeruloplasmin levels

\begin{tabular}{c|c|c}
\hline Case no. & $\begin{array}{c}\text { Total plasma copper } \\
(\mu \mathrm{g} / 100 \mathrm{ml})\end{array}$ & $\begin{array}{c}\text { Plasma caeruloplasmin } \\
(\mathrm{mg} / 100 \mathrm{ml})\end{array}$ \\
\hline 3 & 15 & 3 \\
5 & 34 & 10 \\
4 & 30 & 6 \\
\hline
\end{tabular}

^Case numbers from Danks et al. (1972b).

Radioisotope studies in Case 3 (Danks et al., $1972 b)$ suggested malabsorption of copper, but in
Case 5 (Danks et al., 1972b) this study was unsatisfactory as the child was totally constipated throughout the test period of collection. Oral therapy with copper sulphate in both children failed to raise plasma copper to normal levels.

Once there was evidence that these children had copper malabsorption, attention was directed to therapy of the state of copper deficiency. It was therefore planned, with parental consent, to study one child (Case 3 ) in depth.

Farrer and Mistilis (1967) have shown in the experimental animal that copper absorption is principally by an active process, but large amounts of copper given orally lead to passive absorption of about $10 \%$ of the administered dose. Therefore, oral copper was given to Case 3 as a dilute copper sulphate solution up to a dosage of $10 \mathrm{mg} /$ day, i.e. much more than the normal requirement for copper (for an infant $0.05 \mathrm{mg} / \mathrm{kg}$ per day-National Research Council, 1958). There was some change in plasma total copper levels from $5 \mu \mathrm{g} / 100 \mathrm{ml}$ to 37 $\mu \mathrm{g} / 100 \mathrm{ml}$ after 6 months (Fig.).

Steroids administered to newborn rats have been shown to alter the mechanism of copper absorption from a pinocytic process to active and passive transport (Mearrick and Mistilis, 1969). From this it was postulated that there may have been a failure of this mechanism to be 'turned on', and a one-week course of oral steroids was given to Case 3 while receiving oral copper, but there was no effect on plasma copper levels.

It is known that the parenteral administration to sheep of the chelate, copper EDTA, reverses a state of copper deficiency and that copper accumulates in the liver (Camargo, Lee, and Dewey, 1962). Vagg (1972) has shown in sheep that there is a great variability in retention of various metal ion chelates. There was no previous knowledge of the retention of copper by the body in man where copper EDTA or any other copper complex was given intramuscularly (Medical Journal of Australia, 1972). Therefore, in order to test whether copper given in this way could 


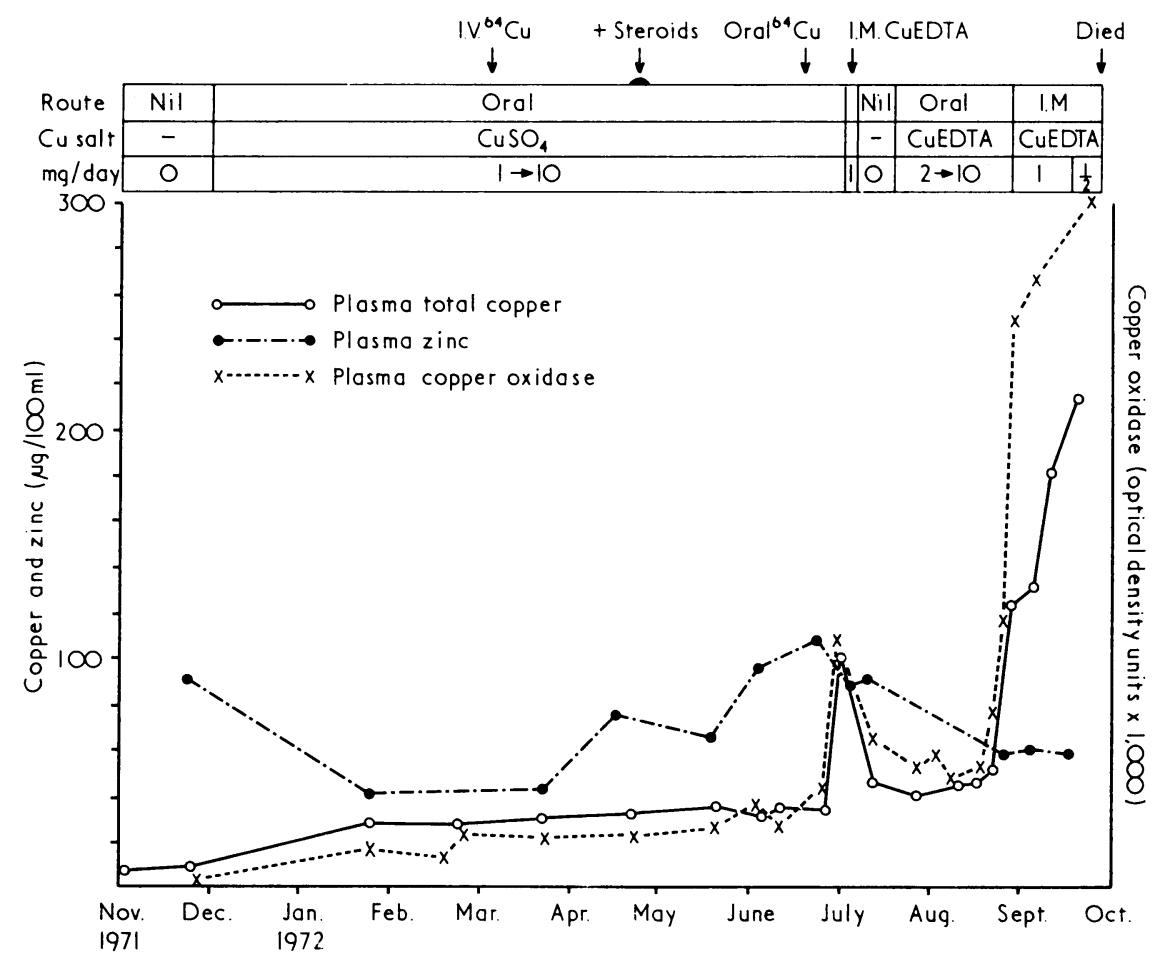

FIG.-Effect of therapy on plasma total copper, plasma zinc, and plasma copper oxidase levels.

be metabolized by the body, two intramuscular injections of copper EDTA totalling $2 \mathrm{mg}$ copper were given, with a significant rise in total plasma copper levels and plasma copper oxidase (Fig.).

As it has been reported in zinc-deficient chickens that zinc-chelated EDTA facilitates the absorption of zinc, and as zinc and copper absorption are closely interrelated, a radio ${ }^{64} \mathrm{Cu}$ EDTA absorption test was performed. The faecal excretions of isotope over a 48-hour period were $92 \cdot 7 \%$ compared with $97 \%$ with ${ }^{64} \mathrm{Cu}$ sulphate, suggesting some improvement in absorption. Therefore, oral copper EDTA was given in increasing dosage of up to $10 \mathrm{mg} \mathrm{Cu}$ each day, but was not absorbed.

Since $2 \mathrm{mg} \mathrm{Cu}$ given by intramuscular injection as copper EDTA had caused plasma copper levels to rise, a course of daily injections of copper EDTA (1 $\mathrm{mg} \mathrm{Cu}$ ) was given and plasma copper and copper oxidase levels rose to normal (Fig.). Unfortunately, the child was now 1 year 2 months old and there was no evidence of any neurological benefit from the rise in plasma copper levels. He subsequently developed bronchopneumonia and died.

In view of the intimate relation between copper and zinc absorption, it is of interest that his plasma zinc level fluctuated widely during the period of observation, but no consistent change in relation to copper therapy was noted.

Tissue studies.

Liver. Liver biopsy and necropsy liver specimens were estimated for copper content (Table IV). All initially contained low levels of copper,

TABLE IV

Liver copper concentration ( $\mu g / g$ dry tissue)

\begin{tabular}{c|c|c}
\hline Case no.* & Biopsy & Necropsy \\
\hline 3 & $20 \cdot 1$ & $34 \cdot 0$ \\
5 & $9 \cdot 4$ & $9 \cdot 0$ \\
4 & $20 \cdot 0$ & $9 \cdot 0$ \\
\hline
\end{tabular}

*Case numbers from Danks et al. (1972b).

but in Case 3, who had been given some parenteral copper, the copper level in the liver at necropsy had risen to within the normal adult range. In Case 5 the figure was the same in life as at death, the interval between biopsy and necropsy being only 2 months. While in Case 4, at necropsy some 8 
months after the biopsy studies, there was a significantly lower level of copper than at biopsy, suggesting continuing copper depletion.

Brain. Estimation of the copper content of cerebral white matter and cortex at necropsy revealed very low levels compared with normal adult controls (Table V).

TABLE V

Brain copper concentrations ( $\mu g / g$ dry tissue)

\begin{tabular}{c|c|c}
\hline Case no. & Cerebral white matter & Cerebral cortex \\
\hline 3 & $7 \cdot 3$ & $4 \cdot 3$ \\
5 & $4 \cdot 0$ & $9 \cdot 5$ \\
4 & $4 \cdot 3$ & $8 \cdot 2$ \\
Adult normal & $20 \cdot 2 \pm 6$ & $30 \cdot 1 \pm 17$ \\
(Cumings, & & \\
1968) & & \\
\hline
\end{tabular}

^Case numbers from Danks et al. (1972b).

\section{Discussion}

Danks and his colleagues in Melbourne (1972a) have described the way in which copper deficiency may account for the genesis of the clinical features of Menkes's steely-hair syndrome.

This study documents the state of copper deficiency in 3 infants with this syndrome. In one infant, after parenteral copper EDTA, there was a rise in plasma copper level and also plasma copper oxidase, which reflects plasma caeruloplasmin levels. Thus the state of copper deficiency was relieved. The rise in plasma copper oxidase level indicated that the liver could synthesize caeruloplasmin once copper was available to it. This supports the view that the defect in Menkes's steely-hair syndrome is one of copper absorption, the state of copper deficiency being restored once the gut is bypassed.

The neurological sequelae of this disorder were unaffected and are unlikely to be reversed once a state of chronic copper deficiency has developed.

Low brain copper levels were found in all 3 children. Reske-Nielsen et al. (1973), however, failed to find any difference between brain copper concentration in a child with Menkes's disease and two controls. This is probably due to the technique they used of studying formalin-fixed specimens, whereas we used ashed specimens. Further work comparing these methods is indicated.

It is probable that infants with Menkes's steelyhair syndrome have adequate copper stores at birth, as clinical manifestations do not appear for a few months. Bile constitutes the main excretory pathway for copper in man. The enterohepatic circulation of copper in man is small, comprising only the low, readily diffusible fraction of biliary copper (Gollan and Deller, 1973), but its likely reduction or abolition in these infants with copper malabsorption would lead them to becoming copper depleted within a few months, the interval depending presumably on the size of their copper stores at birth. However, once symptoms appear, as reported here, the onset of convulsions and clinical deterioration is rapid.

It seems then that intrauterine diagnosis is unlikely, the infant receiving adequate copper from his mother. When there is a family history of a death of a child from Menkes's syndrome, sexing in early pregnancy and abortion when the fetus is found to be male could be advised, but if plasma copper is estimated serially from birth in children born into such families there is a chance that early parenteral copper therapy might be successful in preventing cerebral damage. Intramuscular copper EDTA, with careful monitoring of plasma copper values, offers the best hope of management at present in this disease. Long-term observations of infants with this syndrome treated with parenteral copper will reveal the value of this form of treatment.

Our greatest debt is to Dr. D. M. Danks of the Royal Children's Hospital, Melbourne, who began the study of copper deficiency in Menkes's syndrome; to Dr. B. J. Stevens for liver biopsy copper levels in these patients; to Drs. R. D. K. Reye and P. Bale of the Institute of Pathology, Royal Alexandra Hospital for Children, for pathological studies; and to Mrs. J. Towson of Royal Prince Alfred Hospital, Sydney, for the isotope studies.

\section{REFERENCES}

Blomfield, J., and MacMahon, R. A. (1969). Micro determination of plasma and erythrocyte copper by atomic absorption spectrophotometry. Fournal of Clinical Pathology, 22, 136.

Camargo, W. V. de A., Lee, H. J., and Dewey, D. W. (1962). Suitability of copper preparations for parenteral copper therapy in sheep. Proceedings of the Australian Society of Animal Production, 4, 12.

Cumings, J. N. (1968). Trace metals in the brain and in Wilson's disease. Fournal of Clinical Pathology, 21, 1.

Danks, D. M., Campbell, P. E., Stevens, B. J., Mayne, V., and Cartwright, E. (1972a). Menkes' kinky-hair syndrome. An inherited defect in copper absorption with widespread effects. Pediatrics, 50, 188.

Danks, D. M., Cartwright, E., and Stevens, B. J. (1973). Menkes' steely-hair (kinky-hair) disease. Lancet, 1, 891.

Danks, D. M., Stevens, B. J., Campbell, P. E., Gillespie, J. M., Walker-Smith, J., Blomfield, J., and Turner, B. (1972b). Menkes' kinky-hair syndrome. Lancet, 1, 1100.

Farrer, P., and Mistilis, S. P. (1967). Absorption of exogenous and endogenous biliary copper in the rat. Nature (London), 213, 291.

Gallagher, C. H., and Reeve, V. E. (1971). Copper deficiency in the rat: effect on adenine nucleotide metabolism. Australian Fournal of Experimental Biology and Medical Science, 49, 445.

Gollan, J. L., and Deller, D. J. (1973). Studies on the nature and excretion of biliary copper in man. Clinical Science, 44, 9.

Mearrick, P. T., and Mistilis, S. P. (1969). Excretion of radiocopper by the neonatal rat. Fournal of Laboratory and Clinical Medicine, 74, 421.

Medical fournal of Australia (1972). Editorial. A new genetical disorder of copper metabolism, 2, 291. 
National Research Council, Food and Nutrition Board (1958). Recommended Dietary Allowances, p. 21. U.S. Government Printing Office, Washington, D.C.

Ravin, H. A. (1961). An improved colorimetric enzymatic assay of ceruloplasmin. Fournal of Laboratory and Clinical Medicine, 58, 161.

Reske-Nielsen, E., Lou, H. O. C., Andersen, P., and Vagn-Hansen, P. (1973). Brain-copper concentration in Menkes' disease. Lancet, 1, 613.

Stevens, B. J. (1972). Biological applications of the carbon rod atomizer in atomic absorption spectroscopy. Determination of copper in small samples of tissue. Clinical Chemistry, 18, 1379. Vagg, M. J. (1972). Influence of EDTA on the retention and pathways of excretion of cobalt, copper, iron, manganese and zinc, after parenteral administration to sheep-mineral studies with isotopes in domestic animals. Proceedings of a Symposium of International Atomic Energy Agency, Vienna, 1971.

Correspondence to Dr. J. A. Walker-Smith, Department of Child Health, St. Bartholomew's Hospital, London EC1A 7BE. 